\title{
Effect of Stunting Disease on Yield of Some Sugarcane Varieties in Puerto Rico
}

\author{
Julio H. López-Rosa and José Adsuar ${ }^{1}$
}

\section{INTRODUCTION}

The stunting disease of sugarcane was first recognized in Queensland, Australia in 1945 (1). ${ }^{2}$ Within a decade this disease had been reported from most sugarcane producing areas of the world (2). In Puerto Rico, it was observed by Robinson in 1953, as cited by Hughes and Steindl (2). In 1955, Bruehl experimentally confirmed its occurrence here (3).

The disease presumably is caused by a virus. Affected canes usually show retarded growth and general unthriftiness. However, these symptoms are not reliable indications of the disease. A more dependable character is the orange or reddish discoloration of the vascular bundles. This symptom can be observed in the nodal region when affected stalks are split longitudinally. The symptom also becomes evident when the node is cut across. Observations made using vascular bundle discoloration as a criterion of infection indicated that the disease was widespread in the relatively unimportant commercial varieties Co. 421, H. 371933 and P.R. 1000. Considering the seriousness of the disease in other parts of the world $(2,4,5,6,7)$, and knowing that it represents a threat to our industry, studies were undertaken to determine the effect of this virus on the leading varieties of Puerto Rican canes. The present paper reports the results of our research with 10 such varieties.

\section{MATERIALS AND METHODS}

The experiment was established at the Lajas Substation in the semiarid Southwestern region, where sugarcane is grown under irrigation. A dry area was selected to avoid the chlorotic streak disease which prevails in the humid regions.

The varieties used were B. 37161 , B. 41227 , B. 4362 , Co. 421 , H. 328560 , P.O.J. 2878, P.R. 975, P.R. 980, P.R. 1000, and P.R. 1013. Varieties P.O.J.

IAssociate Plant Pathologist and Plant Pathologist, respectively, Agricultural Experiment Station, Mayagüez Campus, University of Puerto Rico, Río Piedras, P.R. Appreciation is expressed to Dr. M. Rico-Ballester and to Messrs. F. Silvestry, L. Almodóvar, J. A. Quiñones, and A. Sánchez-Miranda for assisting in the field work, and to Drs. B. G. Capó and J. Bird, and Mr. F. Méndez for revising the manuscript and making valuable suggestions. Appreciation also is expressed to Luce and Company for information regarding the cost of the hot water treatment for controlling the stunting disease commercially.

3 Italic numbers in parentheses refer to Literature Cited, p. 159. 
2878 and P.R. 1000 were no longer being recommended to growers at the time the experiment was established, but were included nevertheless because of the need to know if the decline in yields of these varieties was due to this disease. Variety Co. 421 was not a leading cane at the time but was included as a susceptible check. The experiment consisted of two treatments replicated ten times in a partially-balanced, incomplete block design. One treatment consisted of cane derived from seedpieces inoculated with infective juice; the other, of cane grown from seedpieces treated with hot water. The experimental plots were each $1 / 100$ th of an acre in size.

Nurseries to provide inoculated as well as heat-treated cane for the experiment were established at the aforementioned Substation. Seedpieces for the inoculated stock nursery were immersed prior to inoculation in water at $52^{\circ} \mathrm{C}$. for 20 minutes. Inoculation with the stunting disease virus was performed by cutting two-bud seedpieces with a pruning shear under the surface of juice freshly extracted from diseased stalks of the variety Co. .421. At time of planting, the cane from the inoculated stock nursery was reinoculated to insure thorough exposure of the experimental material to the virus. Planting material for the disease-free stock was treated with water at $50^{\circ} \mathrm{C}$. for three hours. Seedpieces were selected from the middle portion of the stalk, which usually is more tolerant to heat treatment (8).

A report from Cuba (9) indicated that rats were able to transmit stunting disease in the field; thus, the nurseries and the experimental plots both were protected by rat-proof fences. Attempts were made to transmit the causal agent via white rats while the experiment was in progress. The results of these trials did not confirm the findings reported from Cuba (10).

The nurseries and the experimental plots were weeded chemically to prevent transmission of the disease via cultivating implements. Machetes used in harvesting were disinfected with 10-percent Lysol before passing from one experimental plot to another.

The plant cane was harvested at 17 months; the first and second ratoons at 12. Ten stalks per plot were gathered at random and examined for symptoms. A similar sample was sent to the laboratory for sucrose content determination. The total weight of the cane from each plot was recorded.

\section{RESULTS AND DISCUSSION}

The percent infection observed on the varieties tested is shown in table 1. The figures given include only those cases in which there was no doubt as to the diagnosis. With several varieties, there were as many doubtful cases as positive ones. As the data indicate, Co. 421 and P.R. 1000 were the only varieties in which cane from inoculated seedpieces showed a very high percentage of infection. This high incidence of disease on inoculated material agrees with the observation that commercial plantings of these varieties 
had a consistently high proportion of affected stools. The heat treatment was not sufficiently effective to cure all the diseased planting material used to establish the original disease-free nursery. This is evidenced by the fact that 8.1 percent infection was observed on the plant cane of variety Co. 421. This is in agreement with experience from Queensland, where hot water treatment to the limit of tolerance of the seedpieces was not effective in eradicating the stunting disease virus from badly diseased cane (11). In Jamaica, however, the diseased setts of Co. 421 were completely cured, as

TABLE 1.-Percent infection of 10 sugarcane varieties inoculated with stunting disease virus

\begin{tabular}{|c|c|c|c|c|c|}
\hline Variety & Treatment & Plant cane & First ratoon & Second ratoon & Combined crop \\
\hline & & Percent & Percent & Percent & Percent \\
\hline \multirow[t]{2}{*}{ B. 37161} & Hot water & 0.0 & 0.0 & 10.8 & 3.4 \\
\hline & Inoculated & 3.0 & 26.6 & 44.8 & 23.6 \\
\hline \multirow[t]{2}{*}{ B. 41227} & Hot water & .0 & .0 & .0 & .0 \\
\hline & Inoculated & .0 & 4.6 & 6.6 & 3.6 \\
\hline \multirow[t]{2}{*}{ B. 4362} & Hot water & .0 & 2.3 & 5.3 & 2.5 \\
\hline & Inoculated & .0 & 9.3 & 8.5 & 5.7 \\
\hline \multirow[t]{2}{*}{ Co. 421} & Hot water & 8.1 & 8.0 & 17.5 & 12.0 \\
\hline & Inoculated & 74.5 & 78.3 & 83.6 & 78.8 \\
\hline \multirow[t]{2}{*}{ H. 328560} & Hot water & .0 & .0 & 1.1 & .3 \\
\hline & Inoculated & 21.0 & 16.1 & 28.1 & 21.8 \\
\hline \multirow[t]{2}{*}{ P.O.J. 2878} & Hot water & .0 & .0 & 1.0 & .3 \\
\hline & Inoculated & 12.0 & 31.8 & 27.9 & 23.5 \\
\hline \multirow[t]{2}{*}{ P.R. 975} & Hot water & .0 & .0 & .0 & .0 \\
\hline & Inoculated & 2.0 & 11.3 & 18.3 & 10.3 \\
\hline \multirow[t]{2}{*}{ P.R. 980} & Hot water & .0 & 1.1 & .0 & .3 \\
\hline & Inoculated & 3.0 & 29.4 & 21.7 & 18.8 \\
\hline \multirow[t]{2}{*}{ P.R. 1000} & Hot water & .0 & 1.0 & 1.1 & .7 \\
\hline & Inoculated & 58.0 & 46.5 & 70.0 & 57.9 \\
\hline \multirow[t]{2}{*}{ P.R. 1013} & Hot water & .0 & .0 & 1.2 & .4 \\
\hline & Inoculated & 1.0 & 8.8 & 8.9 & 6.0 \\
\hline
\end{tabular}

measured by the incidence of internal symptoms in mature cane, by a twohour hot water treatment at $50^{\circ} \mathrm{C}$. (12). The conclusion that the hot water treatment was not effective enough to inactivate all the virus in Co. 421 may also be applicable to other varieties in the experiment. The presence of strains of the virus differing in heat tolerance might explain in part these conflicting results.

The effect of inoculation on percent sucrose is summarized in table 2. There was a significant increase only in the first ratoon of $\mathrm{H}$. 328560 and in the second ratoon of Co. 421. Non-significant increases in percent sucrose content are common in stunting disease-affected canes $(5,6)$. 
As shown by table 3, significant tonnage reductions were evident in inoculated plant cane of varieties B. 37161, B. 4362, Co. 421 , H. 328560 , and P.R. 980; in the first ratoon of H. 328560, P.R. 980, and P.R. 1013; and in the second ratoon of B. 41227 and P.R. 980. No clear pattern of cor-

TABLE 2.-Sucrose percent yield of 10 sugarcane varieties inoculated with stunting disease virus

\begin{tabular}{|c|c|c|c|c|c|c|c|}
\hline \multirow{3}{*}{ Varicty } & \multirow{3}{*}{ Treatment } & \multicolumn{6}{|c|}{ Percent sucrose } \\
\hline & & \multicolumn{2}{|c|}{ Plant cane } & \multicolumn{2}{|c|}{ First ratoon } & \multicolumn{2}{|c|}{ Second ratoon } \\
\hline & & Percent & $\begin{array}{c}\text { Differ- } \\
\text { ence }\end{array}$ & Percent & Difference & Percent & $\begin{array}{l}\text { Differ- } \\
\text { ence }\end{array}$ \\
\hline \multirow[t]{2}{*}{ B. 37161} & Hot water & 10.18 & & 12.94 & & 11.71 & \\
\hline & Inoculated & 10.79 & +.61 & 12.85 & -.09 & 11.74 & +.03 \\
\hline \multirow[t]{2}{*}{ B. 41227} & Hot water & 10.07 & & 12.23 & & 10.98 & \\
\hline & Inoculated & 9.75 & -.32 & 12.35 & +.12 & 11.45 & +.47 \\
\hline \multirow[t]{2}{*}{ B. 4362} & Hot water & 11.78 & & 13.66 & & 12.77 & \\
\hline & Inoculated & 12.13 & +.35 & 14.05 & +.39 & 13.04 & +.27 \\
\hline \multirow[t]{2}{*}{ Co. 421} & Hot water & 9.70 & & 11.33 & & 10.20 & \\
\hline & Inoculated & 10.20 & +.50 & 11.92 & +.59 & 11.19 & +.991 \\
\hline \multirow[t]{2}{*}{ H. 328560} & Hot water & 11.34 & & 12.78 & & 12.20 & \\
\hline & Inoculated & 11.83 & +.49 & 13.85 & $+1.07^{2}$ & 12.95 & +.75 \\
\hline \multirow[t]{2}{*}{ P.O.J. 2878} & Hot water & 10.87 & & 12.72 & & 12.33 & \\
\hline & Inoculated & 11.76 & +.89 & 13.21 & +.49 & 12.53 & +.20 \\
\hline \multirow[t]{2}{*}{ P.R. 975} & Hot water & 12.84 & & 13.54 & & 13.14 & \\
\hline & Inoculated & 11.88 & -.96 & 13.56 & +.02 & 12.95 & -.19 \\
\hline \multirow[t]{2}{*}{ P.R. 980} & Hot water & 11.57 & & 12.37 & & 11.52 & \\
\hline & Inoculated & 11.94 & +.37 & 12.94 & +.57 & 12.13 & +.61 \\
\hline \multirow[t]{2}{*}{ P.R. 1000} & Hot water & 11.01 & & 13.46 & & 12.22 & \\
\hline & Inoculated & 11.12 & +.11 & 13.63 & +.17 & 12.81 & +.59 \\
\hline \multirow[t]{2}{*}{ P.R. 1013} & Hot water & 12.11 & & 12.99 & & 12.38 & \\
\hline & Inoculated & 12.23 & +.12 & 13.45 & +.46 & 12.72 & +.34 \\
\hline \multirow[t]{2}{*}{ LSD } & .01 & & 1.39 & & 0.98 & & 1.20 \\
\hline & .05 & & 1.06 & & 0.74 & & 0.91 \\
\hline
\end{tabular}

1 Significant difference at the 5-percent level.

2 Significant difference at the 1-percent level.

relation between percent infection (table 1 ) and yield reduction was evident. For instance, in the plant crop, variety B. 4362 had a significant 15.3 percent yield reduction with no detectable infection, while variety P.R. 1000 had no significant reduction with 58.0 percent infection. In the second ratoon, variety $B .41227$ had a highly significant reduction of 18.5 percent with 6.6 percent infection, while P.R. 1000 had no significant reduction with 70.0 percent infection. The high yield reductions in the presence of few or 
TABLE 3.-Yield in tons of cane per acre of 10 sugarcane varieties inoculated with stunting diseasc virus

\begin{tabular}{|c|c|c|c|c|c|c|c|c|c|c|}
\hline \multirow{4}{*}{ Variety } & \multirow{4}{*}{ Treatment } & \multicolumn{9}{|c|}{ Tons of cane per acre } \\
\hline & & \multicolumn{3}{|c|}{ Plant cane } & \multicolumn{3}{|c|}{ First ratoon } & \multicolumn{3}{|c|}{ Second ratoon } \\
\hline & & \multicolumn{3}{|c|}{ Difference in yield } & \multicolumn{3}{|c|}{ Difference in yield } & \multicolumn{3}{|c|}{ Difference in yield } \\
\hline & & Yield & Tons & Percent & Yield & Tons & Percent & Yield & Tons & Percent \\
\hline $\begin{array}{l}\text { B. } 37161 \\
\text { B. } 41227 \\
\text { B. } 4362 \\
\text { Co. } 421 \\
\text { H. } 328560 \\
\text { P.O.J. } 2878 \\
\text { P.R. } 975 \\
\text { P.R. } 980 \\
\text { P.R. } 1000 \\
\text { P.R. } 1013 \\
\text { LSD }\end{array}$ & $\begin{array}{c}\text { Hot water } \\
\text { Inoculated } \\
\text { Hot water } \\
\text { Inoculated } \\
\text { Hot water } \\
\text { Inoculated } \\
\text { Hot water } \\
\text { Inoculated } \\
\text { Hot water } \\
\text { Inoculated } \\
\text { Hot water } \\
\text { Inoculated } \\
\text { Hot water } \\
\text { Inoculated } \\
\text { Hot water } \\
\text { Inoculated } \\
\text { Hot water } \\
\text { Inoculated } \\
\text { Hot water } \\
\text { Inoculated } \\
.01 \\
.05\end{array}$ & $\begin{array}{l}131.7 \\
103.5 \\
134.2 \\
126.5 \\
134.7 \\
114.0 \\
131.4 \\
111.0 \\
136.9 \\
109.4 \\
119.9 \\
105.8 \\
134.3 \\
126.7 \\
144.6 \\
120.1 \\
116.6 \\
103.6 \\
140.4 \\
128.6\end{array}$ & $\begin{array}{r}-28.2^{2} \\
-7.7 \\
-20.7^{1} \\
-20.4^{1} \\
-27.5^{2} \\
-14.1 \\
-7.6 \\
-24.5^{2} \\
-13.0 \\
-11.8 \\
21.2 \\
16.1\end{array}$ & $\begin{array}{r}-21.4 \\
-5.7 \\
-15.3 \\
-15.5 \\
-20.0 \\
-11.7 \\
-5.6 \\
-16.9 \\
-11.1 \\
-8.4\end{array}$ & $\begin{array}{l}71.7 \\
64.9 \\
80.8 \\
70.9 \\
70.4 \\
65.6 \\
77.6 \\
69.7 \\
69.3 \\
54.6 \\
54.9 \\
52.9 \\
76.5 \\
69.8 \\
86.0 \\
66.0 \\
68.2 \\
58.8 \\
79.8 \\
65.3\end{array}$ & $\begin{array}{r}-6.8 \\
-9.9 \\
-4.8 \\
-7.9 \\
-14.7^{1} \\
-2.0 \\
-6.7 \\
-20.0^{2} \\
-9.4 \\
-14.5^{1} \\
17.5 \\
13.3\end{array}$ & $\begin{array}{r}-9.4 \\
-12.2 \\
-6.8 \\
-10.1 \\
-21.2 \\
-3.6 \\
-8.7 \\
-23.2 \\
-13.7 \\
-18.1\end{array}$ & $\begin{array}{l}70.2 \\
65.4 \\
95.2 \\
77.5 \\
72.0 \\
60.3 \\
85.7 \\
73.7 \\
66.3 \\
63.0 \\
66.5 \\
55.5 \\
72.3 \\
69.6 \\
89.8 \\
69.0 \\
73.4 \\
67.4 \\
81.7 \\
72.5\end{array}$ & $\begin{array}{r}-4.8 \\
-17.7^{2} \\
-11.7 \\
-12.0 \\
-3.3 \\
-11.0 \\
-2.7 \\
-20.8^{2} \\
-6.0 \\
-9.2 \\
17.0 \\
12.9\end{array}$ & $\begin{array}{r}-6.8 \\
-18.5 \\
-16.2 \\
-14.0 \\
-4.9 \\
-16.5 \\
-3.7 \\
-23.1 \\
-8.1 \\
-11.2\end{array}$ \\
\hline
\end{tabular}

1 Significant difference at the 5-percent level.

Significant difference at the 1-percent level. 
no symptoms suggest that the disease remains masked in these varieties. Lack of statistically measurable yield reductions in P.R. 1000 and P.O.J. 2878 suggests that these varieties are highly tolerant to the causal agent under the conditions of this experiment and that stunting disease may not be responsible for their decline. In Queensland, however, stunting disease caused significant tonnage reductions on variety P.O.J. 2878 (13).

Table 4 summarizes the results of inoculating seedpieces with the stunting disease virus on hundredweights of sugar per acre. In the plant crop, yields of five varieties were significantly reduced by inoculation. The case of variety P.R. 975 was interesting. A significant reduction of $\mathbf{4 3 . 0}$ hundredweights of sugar per acre occurred in this variety, while sucrose and tonnage reductions were not statistically significant. The very important commerical cane P.R. 980 was the only one that showed consistent significant reduction in tonnage (table 3) and sugar per acre (table 4) throughout the experiment.

Table 5 presents the average production of the plant and the two ratoon crops. In the combined crop, percent sucrose was significantly higher in Co. 421 and H. 328560 canes derived from inoculated seedpieces. Cane and sugar reductions due to inoculation were significant in seven varieties.

A report from Brazil stated that $H$. 328560 was totally destroyed by the stunting disease (14). In the present trial, this variety suffered only a small, though significant, reduction in sugar per acre in the combined crop.

At the time the trial was set, seven of the test varieties were being recommended to growers by the Experiment Station. Recommendations were based on superior yielding capacity and resistance to mosaic. Only varieties H. 328560, P.R. 975, P.R. 980, and P.R. 1013 presently are being recommended. P.R. 980, which occupies 60 percent of the sugarcane acreage, was the most severely affected variety. It showed a highly significant yield reduction due to inoculation with the stunting disease virus of 42.4 hundredweights of sugar per acre per crop. Had this experiment been a commercial operation, the grower's profit would have been reduced by $\$ 170$ per acre per crop. This figure is estimated by using the average liquidation price of $\$ 6.23$ per hundredweight of raw sugar paid for the 1964-65 crop when grower participation was 64.7 percent. However, hot water treatment of the seedpieces would have reduced the profit only by $\$ 65.48$ per acre per crop. This figure is an estimate of the cost of treating the cane $(\$ 2.50$ per acre) plus the cost (\$62.98 per acre) of harvesting and hauling 22.1 additional tons of cane produced as a result of the heat treatment.

To get as clear a picture as possible of the effect of the stunting disease on yield of sugar per acre, the experiment had to be carried out with a minimum of complication from the chlorotic streak disease. For this reason, the trial was performed in a low rainfall area where sugarcane is grown under irrigation. Thus, it is expected that the results obtained in these 
TABLE 4.-Yield in hundredweights of sugar per acre of 10 sugarcane varieties inoculated with stunting disease virus

\begin{tabular}{|c|c|c|c|c|c|c|c|c|c|c|}
\hline \multirow{4}{*}{ Variety } & \multirow{4}{*}{ Treatment } & \multicolumn{9}{|c|}{ Hundredweights of sugar per acre } \\
\hline & & \multicolumn{3}{|c|}{ Plant cane } & \multicolumn{3}{|c|}{ First ratoon } & \multicolumn{3}{|c|}{ Second ratoon } \\
\hline & & \multicolumn{3}{|c|}{ Difference in yield } & \multicolumn{3}{|c|}{ Difference in yield } & \multicolumn{3}{|c|}{ Difficrence in yield ${ }^{-}$} \\
\hline & & Yield & $\begin{array}{c}\text { Hundred- } \\
\text { weights }\end{array}$ & Percent & Yield & $\begin{array}{c}\text { Hundred- } \\
\text { weights }\end{array}$ & Percent & Yield & $\underset{\substack{\text { Hundred- } \\
\text { weights }}}{\text { Huts }}$ & Percent \\
\hline $\begin{array}{l}\text { B. } 37161 \\
\text { B. } 41227 \\
\text { B. } 4362 \\
\text { Co. } 421 \\
\text { H. } 328560 \\
\text { P.O.J. } 2878 \\
\text { P.R. } 975 \\
\text { P.R. } 980 \\
\text { P.R. } 1000 \\
\text { P.R. } 1013\end{array}$ & $\begin{array}{c}\text { Hot water } \\
\text { Inoculated } \\
\text { Hot water } \\
\text { Inoculated } \\
\text { Hot water } \\
\text { Inoculated } \\
\text { Hot water } \\
\text { Inoculated } \\
\text { Hot water } \\
\text { Inoculated } \\
\text { Hot water } \\
\text { Inoculated } \\
\text { Hot water } \\
\text { Inoculated } \\
\text { Hot water } \\
\text { Inoculated } \\
\text { Hot water } \\
\text { Inoculated } \\
\text { Hot water } \\
\text { Inoculated } \\
\quad .01 \\
.05\end{array}$ & $\begin{array}{l}269.1 \\
222.2 \\
271.0 \\
244.6 \\
314.6 \\
272.8 \\
252.6 \\
225.7 \\
311.1 \\
256.2 \\
259.4 \\
248.0 \\
343.2 \\
300.2 \\
332.5 \\
286.2 \\
255.2 \\
230.1 \\
341.6 \\
315.1\end{array}$ & $\begin{array}{r}-46.9^{1} \\
-26.4 \\
-41.8^{1} \\
-26.9 \\
-54.9^{2} \\
-11.4^{2} \\
-43.0^{2} \\
-46.3^{1} \\
-25.1 \\
-26.5 \\
53.0 \\
40.2\end{array}$ & $\begin{array}{r}-17.4 \\
-9.7 \\
-13.2 \\
-10.6 \\
-17.6 \\
-4.3 \\
-12.5 \\
-13.9 \\
-9.8 \\
-7.7\end{array}$ & $\begin{array}{l}184.9 \\
165.9 \\
196.6 \\
171.3 \\
190.6 \\
181.8 \\
175.7 \\
165.4 \\
176.3 \\
151.2 \\
137.1 \\
139.0 \\
207.1 \\
188.5 \\
212.2 \\
170.4 \\
181.9 \\
158.8 \\
207.5 \\
175.3\end{array}$ & $\begin{array}{r}-19.0 \\
-25.3 \\
-8.8 \\
-10.3 \\
-25.1 \\
+1.9 \\
-18.6 \\
-41.8^{2} \\
-23.1 \\
-32.2^{1} \\
40.4 \\
30.6\end{array}$ & $\begin{array}{r}-10.2 \\
-12.8 \\
-4.6 \\
-5.8 \\
-14.2 \\
+1.3 \\
-8.9 \\
-19.7 \\
-12.7 \\
-15.5\end{array}$ & $\begin{array}{l}162.2 \\
153.3 \\
207.3 \\
174.9 \\
182.6 \\
155.9 \\
173.7 \\
163.6 \\
160.5 \\
162.3 \\
162.5 \\
138.5 \\
188.6 \\
179.1 \\
206.4 \\
167.1 \\
178.2 \\
170.8 \\
202.0 \\
183.6\end{array}$ & $\begin{array}{r}-8.9 \\
-32.4^{1} \\
-26.7 \\
-10.1 \\
+1.8 \\
-24.0 \\
-9.5 \\
-39.3^{2} \\
-7.4 \\
-18.4 \\
37.1 \\
28.1\end{array}$ & $\begin{array}{r}-5.4 \\
-15.6 \\
-14.6 \\
-5.8 \\
+1.1 \\
-14.7 \\
-5.0 \\
-19.0 \\
-4.1 \\
-9.1\end{array}$ \\
\hline
\end{tabular}

${ }^{1}$ Significant difference at the 5-percent level.

2 Significant difference at the 1-percent level. 
TABLE 5.-Sucrose percent yield, tons of cane per acre and hundredweights of sugar per acre of the combined crop of 10 sugarcane varieties inoculated with stunting disease virus

\begin{tabular}{|c|c|c|c|c|c|c|c|c|c|}
\hline \multirow{4}{*}{ Variety } & \multirow{4}{*}{ Treatment } & \multicolumn{8}{|c|}{ Combined crop } \\
\hline & & \multirow{2}{*}{\multicolumn{2}{|c|}{ Percent sucrose }} & \multirow{2}{*}{\multicolumn{3}{|c|}{$\frac{\text { Tons of cane per acre }}{\text { Difference in yield }}$}} & \multirow{2}{*}{\multicolumn{3}{|c|}{$\begin{array}{c}\text { Hundredweights of sugar per acre } \\
\text { Difference in yield }\end{array}$}} \\
\hline & & & & & & & & & \\
\hline & & Percent & Difference & Yield & Tons & Percent & Yield & $\begin{array}{c}\text { Hundred- } \\
\text { weights }\end{array}$ & Percent \\
\hline $\begin{array}{l}\text { B. } 37161 \\
\text { B. } 41227 \\
\text { B. } 4362 \\
\text { Co. } 421 \\
\text { H. } 328560 \\
\text { P.O.J. } 2878 \\
\text { P.R. } 975 \\
\text { P.R. } 980 \\
\text { P.R. } 1000 \\
\text { P.R. } 1013\end{array}$ & $\begin{array}{l}\text { Hot water } \\
\text { Inoculated } \\
\text { Hot water } \\
\text { Inoculated } \\
\text { Hot water } \\
\text { Inoculated } \\
\text { Hot water } \\
\text { Inoculated } \\
\text { Hot water } \\
\text { Inoculated } \\
\text { Hot water } \\
\text { Inoculated } \\
\text { Hot water } \\
\text { Inoculated } \\
\text { Hot water } \\
\text { Inoculated } \\
\text { Hot water } \\
\text { Inoculated } \\
\text { Hot water } \\
\text { Inoculated } \\
\quad .01 \\
.05\end{array}$ & $\begin{array}{l}11.61 \\
11.79 \\
11.09 \\
11.18 \\
12.74 \\
13.07 \\
10.41 \\
11.10 \\
12.11 \\
12.88 \\
11.97 \\
12.50 \\
13.17 \\
12.80 \\
11.82 \\
12.34 \\
12.23 \\
12.52 \\
12.49 \\
12.80\end{array}$ & $\begin{array}{l}+.18 \\
+.09 \\
+.33 \\
+.691 \\
+.77^{1} \\
+.53 \\
-.37 \\
+.52 \\
+.29 \\
+.31 \\
0.82 \\
0.62\end{array}$ & $\begin{array}{r}91.2 \\
77.9 \\
103.4 \\
91.6 \\
92.3 \\
79.9 \\
98.2 \\
84.8 \\
91.0 \\
75.6 \\
80.4 \\
71.4 \\
94.4 \\
88.7 \\
106.8 \\
85.0 \\
86.1 \\
76.6 \\
100.6 \\
88.8\end{array}$ & $\begin{array}{r}-13.5^{1} \\
-11.8^{1} \\
-12.4^{1} \\
-13.4^{1} \\
-15.4^{2} \\
-9.0 \\
-5.7 \\
-21.8^{2} \\
-9.5 \\
-11.8^{1} \\
14.1 \\
10.7\end{array}$ & $\begin{array}{l}-14.6 \\
-11.4 \\
-13.4 \\
-13.6 \\
-16.9 \\
-11.9 \\
-6.0 \\
-20.4 \\
-11.0 \\
-11.7\end{array}$ & $\begin{array}{l}205.4 \\
180.5 \\
224.9 \\
196.9 \\
229.2 \\
203.5 \\
200.6 \\
184.9 \\
215.9 \\
189.9 \\
186.3 \\
175.2 \\
246.3 \\
222.6 \\
250.3 \\
207.9 \\
205.1 \\
186.5 \\
250.3 \\
224.6\end{array}$ & $\begin{array}{l}-24.9^{2} \\
-28.0^{1} \\
-25.7^{1} \\
-15.7 \\
-26.0^{1} \\
-11.1 \\
-23.7^{1} \\
-42.4^{2} \\
-18.6 \\
-25.7^{1} \\
31.4 \\
23.7\end{array}$ & $\begin{array}{r}-12.1 \\
-12.4 \\
-11.2 \\
-7.8 \\
-12.0 \\
-5.9 \\
-9.6 \\
-16.9 \\
-9.0 \\
-10.2\end{array}$ \\
\hline
\end{tabular}

1 Significant difference at the 5-percent level.

Significant difference at the 1-percent level. 
studies might be applicable to the varieties tested when these are grown on irrigated as well as in humid land. In the few low rainfall areas where sugarcane is grown without irrigation, greater reductions in yield should be expected from the stunting disease, because water stresses aggravate the effects of the disease $(14,15,16,17)$.

\section{SUMMARY}

The effect of the ratoon stunting disease virus was studied on yield of cane and sugar per acre of varieties B. 37161, B. 41227, B. 4362, Co. 421, H. 328560, P.O.J. 2878, P.R. 975, P.R. 980, P.R. 1000, and P.R. 1013.

A 3-hour hot water treatment at $50^{\circ} \mathrm{C}$. did not eradicate the virus in most varieties, assuming that all were initially infected, but this treatment furnished very good control, except in Co. 421.

In the combined crop of plant cane and two ratoons, percent sucrose increase due to inoculation was statistically significant in varieties $\mathbf{H}$. 328560 and Co. 421.

Tonnage of cane per acre was significantly reduced by inoculation in seven varieties. The canes affected and the percent yield reductions were, respectively, as follows: B. 37161, 14.6; B. 41227, 11.4; B. 4362, 13.4; Co. 421, 13.6; H. 328560, 16.9; P.R. 980, 20.4; and P.R. 1013, 11.8.

Production of sugar per acre per crop was reduced significantly in seven varieties as a result of reduced tonnage. The varieties affected and the percent yield reductions were, respectively, as follows: B. 37161, 12.1; B. 41227, 12.4; B. 4362, 11.2; H. 328560, 12.0; P.R. 975, 9.6; P.R. 980, 16.9; and P.R. 1013, 10.2 .

There were significant reductions of cane and sugar per acre per crop in some varieties, especially in B. 41227, B. 4362, and P.R. 1013 although detectable infection in the combined crop of these varieties was only 3.6, 5.7 , and 6.0 percent, respectively. The absence of symptoms in these canes suggests the presence of masked infections.

The production of sugar per acre per crop of varieties Co. 421 and P.R. 1000 was not significantly reduced in the combined analysis in spite of the high disease incidence (78.8 and 57.9 percent infection, respectively). The lack of significance in Co. 421 was attributable to a significant increase in percent sucrose in inoculated cane in addition to infection of the controls. Varieties P.R. 1000 and P.O.J. 2878 are considered tolerant to the stunting disease. It appears that the disease is not responsible for decline in their yield.

Varieties H. 328560, P.R. 975, P.R. 980, and P.R. 1013, in all of which occurred significant reductions in sugar per acre due to the stunting disease, are the only ones of the group tested presently being recommended to growers by the Experiment Station on the basis of other desirable qualities. 
Variety P.R. 980; which occupies 60 percent of the sugarcane acreage, showed a highly significant yield reduction of 42.4 hundredweights of sugar per acre per crop as a result of inoculation with the stunting disease agent. Had this experiment been a commercial operation, profit to the grower would have been reduced by $\$ 170$ per acre per crop, estimated at the average liquidation price of $\$ 6.23$ per hundredweight of raw sugar for the 1964-65 crop, when grower participation was 64.7 percent.

\section{RESUMEN}

Se determinó el efecto del virus causante del enanismo en la producción de caña y azúcar de las variedades B. 37161, B. 41227, B. 4362, Co. 421, H. 328560, P.O.J. 2878, P.R. 975, P.R. 980, P.R. 1000 y P.R. 1013.

El tratamiento con agua caliente a $50^{\circ} \mathrm{C}$. por 3 horas no erradicó el agente etiológico en la mayoría de las variedades; se presume que todas estaban inicialmente infectadas. No obstante, se logró un control muy efectivo, excepto en la Co. 421.

En la cosecha combinada, a sea el promedio de la plantilla y dos retoños, el porcentaje de sacarosa fue significativamente mayor en la cafia inoculada de las variedades H. 328560 y Co. 421.

El tonelaje de caña por acre por cosecha se redujo significativemente como resultado de la inoculación en siete de las variedades. Las variedades afectadas, con sus respectivos por cientos de reducción, fueron las siguientes: B. 37161 , 14.6; B. 41227, 11.4; B. 4362, 13.4; Co. 421, 13.6; H. 328560, 16.9; P.R. 980, 20.4 y P.R. 1013, 11.8. Hubo una reducción significativa en las producción de azúcar por acre por cosecha en siete de las variedades como resultado de la merma en el tonelaje de caña debido a la inoculación. Las variedades afectadas, con sus respectivos por cientos de reducción, fueron las siguientes: B. 37161, 12.1; B. 41227, 12.4; B. 4362, 11.2; H. 328560 , 12.0; P.R. 975, 9.6; P.R. 980, 16.9 y P.R. 1013, 10.2.

Hay indicios de que el virus está presente en algunas variedades aunque las mismas no presenten sintomas. Esto parece suceder en el caso de las variedades B. 41227, B. 4362 y P.R. 1013, ya que hubo mermas significativas de caña y azúcar por acre por año mientras la infección detectable en la cosecha combinada de estas tres variedades fue sólo de 3.6, 5.7 y 6.0, respectivamente.

La producción de azúcar por acre por cosecha de las variedades Co. 421 y P.R. 1000 no se redujo significativamente a pesar de los altos por cientos de infección (78.8 y 57.9, respectivamente) en la cosecha combinada. El hecho de que la variedad Co. 421 no se afectara significativamente puede atribuirse al aumento significativo en sarcarosa en la caña inoculada y a la infección de los testigos. Las variedades P.R. 1000 y P.O.J. 2878 son con- 
sideradas tolerantes al enanismo. La enfermedad, aparentemente, no es causa de los bajos rendimientos de estas variedades.

Las variedades H. 328560, P.R. 975, P.R. 980 y P.R. 1013, las cuales sufrieron mermas significativas en la producción de azúcar por acre debido al enanismo, son las únicas entre las 10 inoculadas que recomienda al presente la Estación Experimental.

La variedad P.R. 980, la cual ocupa el 60 por ciento del área dedicada a cańa, mostró una reducción altamente significativa de 42.4 quintales de azúcar por acre por cosecha como resultado de la inoculación con el agente causal del enanismo. De haber sido esta una operación comercial, la ganancia del agricultor se hubiera reducido en $\$ 170$ por acre por cosecha, estimado a base del precio promedio de liquidación de $\$ 6.23$ por quintal de azúcar cruda para la zafra de 1964-65 cuando la participación del colono fue 64.7 por ciento.

\section{LITERATURE CITED}

1. Mungomery, R. W., Rep. Bur. Sugar Expt. Sta., Queensland 49: 41-2, 1949.

2. Hughes, C. G., and Steindl, D. R. L., Ratoon stunting disease of sugarcane, Bur. Sugar Expt. Sta., Queensland, Tech. Comm. No. 2, 1955.

3. Bruehl, G. W., Evidence indicating presence of the ratoon stunting virus disease of sugarcane in Puerto Rico, Pl. Dis. Rptr., ARS, USDA 99: 157-8, 1955.

4. Schexnayder, C. A., The effect of stunting disease of sugarcane on yields of cane and sugar in Louisiana and the use of hot water treatment for control, Sugar Bull. 34: 349-55, 1956.

5. - and Abbott, E. V., Study during 1956 of the effects of stunting disease on yields of cane and sugar in Louisiana, Sugar Bull. 35: 334-9, 1957.

6. Steib, R. J., Forbes, I. L., and Chilton, S. J.P., Studies of the effects of the ratoon stunting disease on yields of sugarcane varieties presently grown in Louisiana, Sugar Bull. 36: 163-9, 1958.

7. - Heat treating method for controlling ratoon stunting disease, Sugar J. 81: 22-3, 26, 28, 1958.

8. Adsuar, J., and López-Rosa, J.H., Effect of hot-water treatment for the control of ratoon stunting disease on the germination of some commercial sugarcane varieties, J. Agr. Univ. P.R. \&6 (2): 83-6, 1962.

9. Wehlburg, C., Ratoon stunting disease in Cuba, Sugar 51: 27-9, 1956.

10. Adsuar, J., Failure of rats to transmit the causal agent of the sugarcane ratoon stunting disease, J. Agr. Univ. P.R. 46 (3): 239-40, 1962.

11. Hughes, C. G., Steindl, D. R. L., Sturgess, O. W., and Egan, B. T., Rep. Bur. Sugar Expt. Sta., Quesnsland 64: 66-82, 1964.

12. Annual Report of the Research Department, Sugar Manufacturers Association of Jamaica, 22-4, 1955.

13. Steindl, D. R. L., Rep. Bur. Sugar Expt. Sta., Queensland 66: 72-80, 1955.

14. Vêiga, F.M., Notas sobre o raquitismo das socas em campos, Brasil Acucareiro 47: 81-3, 1956.

15. Steib, R. J., Forbes, I. L., and Chilton, S. J. P., A report on further studies on the ratoon stunting disease of sugarcane in Louisiana, Sugar J. New Orleans 19: 35-7, 1957. 
16. Steindl, D. R. L., Ratoon stunting disease. In Sugarcane Diseases of the World, Vol. 1 pp. 433-459. Elsevier Publishing Company, Amsterdam, London, New York, Princeton, 542 pp., 1961.

17. Wang, C. S., Relationships between some environmental factors and cane yield with ratoon stunting disease. I. Soil moisture content, Rep. Taiwan Sugar Expt. Sta. 88: 81-9, 1965. 